\title{
EDUKASI KESEHATAN MASYARAKAT DI BANTARAN SUNGAI LULUT SEBAGAI UPAYA MITIGASI BENCANA BANJIR
}

\author{
Husnul Khatimah ${ }^{1}$, Siti Kaidah ${ }^{1}$, Lia Yulia Budiarti ${ }^{2}$ \\ ${ }^{1}$ Departemen Biomedik, Fakultas Kedokteran Universitas Lambung Mangkurat \\ ${ }^{2}$ Departemen Mikrobiologi Parasitologi, Fakultas, Kedokteran Universitas Lambung Mangkurat \\ khatynunul@gmail.com, siti.kaidah@ulm.ac.id, 1ybudiarti@ulm.ac.id,
}

\begin{abstract}
Abstrak
Dampak dari bencana banjir bandang yang terjadi pada awal tahun 2021 di selruh wilayah kota Banjarmasin, menyisakan lingkungan yang kurang sehat. Wilayah Sungai Lulut, merupakan wilayah terbesar yang terdampak akibat bencana banjir. Hasil analisis situasi lingkungan pada masyarakat di bantaran Sungai Lulut Banjarmasin didapatkan perilaku kurang higienis dalam penerapan PHBS dalam keluarga dan menjaga kesehatan di lingkungan masyarakatnya. Bencana banjir senantiasa memiliki potensi untuk kembali terjadi, sehingga diperlukan sosialisai dan edukasi pada masyarakat untuk menerapkan PHBS dan berperan aktif dalam menjaga kesehatan lingkungannya. Kegiatan ini bertujuan memberikan pengetahuan dan pemahaman dalam menjaga kesehatan masyarakat di lingkungan bantaran sungai sebagai upaya mitigasi bencana banjir. Mitra sasaran adalah ibu-ibu rumah tangga. Metode edukasi dilkasanakan secara lansung pada mitra sasaran berupa edukasi penerapan PHBS dalam keluarga dan masyarakat, serta upaya mitigasi bencana banjir. Hasil kegiatan, didapatkan lebih dari $75 \%$ mitra sasaran paham mengenai pentingnya penerpan PHBS dalam keluarga dan masyarakat dan penerapan menjaga kesehatan dilingkungan bantaran sungai sebagai upaya mitigasi bencana banjir. Diharapkan mitra sasaran dapat menerapkan PHBS yang berkelanjutan dan turut berperan aktif dalam menjaga lingkungan bantaran sungai.
\end{abstract}

Kata Kunci : bantaran sungai Lulut, edukasi, kesehatan masyarakat, mitigasi banjir.

\section{PENDAHULUAN}

Kelurahan Sungai Lulut merupakan bagian wilayah Kecamatan Banjarmasin Timur, yang memiliki wilayah paling luas dibandingkan kelurahan lainnya di Kota Banjarmasin yaitu 8,63 $\mathrm{Km}^{2}$, dengan kondisi topografis terletak pada ketinggian tempat rata-rata $0.16 \mathrm{~m}$ dibawah permukaan laut (dpl) dan hampir seluruh wilayah dialiri oleh Sungai Martapura dan bermuara di Sungai Barito Kondisi ini menjadikan wilayah ini setiap tahun mengalami banjir (Kelurahan Sungai Lulut, 2020). Pada bencana banjir bandang Januari 2021 terdapat $1.585 \mathrm{KK}$ atau 3.701 jiwa pengungsi yang sebagian besar merupakan warga Sungai Lulut (BPBD Kota Banjarmasin, 2021).

Hasil penagamatan awal, memperlihatkan adanya dampak setelah banjir pada masyarakat, diantaranya yaitu banyak rumah masyarakat dan linkungannya di wilayah ini yang kotor dan tidak higienis; terdapat tumpukan sampah digenangi air hujan di jalan-jalan umum dan menutupi selokan, 
serta sampah disekitar bantaran sungai. Dampak lainnya adalah keterbatasan ketersedian air bersih, dan sumber air serta tempat penampungan air dalam rumah tangga menjadi kotor. Informasi dari masyarakat di wilayah ini menyebutkan belum ada suatu kegiatan atau informasi kepada masyarakat setelah terjadi wabah bencana banjir tentang upaya yang dapat dilakukan oleh masyarak berkaitan dengan aspek kesehatan lingkungan masyarakat di bantaran sungai tersebut pasca bencana banjir terjadi.

Bencana banjir menyebabkan peningkatan cemaran mikroba pada sumber air yang digunakan masyarakat karena mikroba yang terbawa oleh air , air sungai yang melupa, dan dari air tanah. Air lindi yang tercemar mikroba dapat masuk kedalam system aliran air perpipaan bersama dengan luapan air hujan. Cemaran bakteri pada air sungai atau air yang digunakan oleh seserorang juga dapat menjadikan seseorang berperan sebagai karier dan menularkan penyakit infeksi pada orang lain (Budiarti, 2017).

Keterbatasan air bersih saat bencana banjir dan pola hidup masyarakat di bantaran sungai yang kurang hygiene dapat menyebabkan penyakit infeksi berulang disaat terjadinya bencana banjir. Data puskesmas wilayah kerja Sungai Lulut tahun 2019, menyebutkan bahwa penyakit infeksi termasuk 5 kasus tertinggi. Menurut Riskesdas 2019, angka kejadian penyakit infeksi yang tinggi berkaitan dengan perilaku buang air di jamban sehat, dimana Kalimantan Selatan berada pada posisi 5 terendah dibawah angka nasional mengenai perilaku buang air di jamban sehat, atau berada di bawah rata-rata angka nasional dengan besar $80 \%$ yang berperilaku BAB di jamban sehat. Sehingga faktor jamban sehat yang berkaitan dengan BAB dan jarak jamban dari sungai menjadi salah satu faktor terjadinya penularan penyakit infeksi pada masyarakat yang tinggal di bantaran sungai. (Riskesdas,2019) Faktor jamban mempengaruhi cemaran bakteri pada air sungai atau aliran air di lingkungan bantaran sungai, serta kolonisasi bakteri pada tangan (Budiarti, 2017)

Bencana banjir senantiasa memiliki potensi untuk kembali terjadi, sehingga sangat penting dilakukannya mitigasi bencana banjir, untuk mengantisipasi dampak dari bencana tersebut. Mitigasi dilakukan untuk mengurangi risiko bencana bagi masyarakat yang berada pada kawasan rawan bencana. (Hermon, 2012; Lindarto et al., 2018; Shalihati et al., 2016). Menurut UU No. 24 Tahun 2007, kegiatan mitigasi dapat dilakukan melalui penyelenggaraan pendidikan, penyuluhan dan pelatihan baik secara konvensional maupun modern. (Hermon, 2012).

Pengetahuan dalam menjaga kesehatan masyarakat di lingkungan bantaran sungai sebagai upaya mitigasi bencana banjir menjadi sebuah hal yang penting untuk ditingkatkan; karena pengetahuan merupakan salah satu aspek penting untuk bisa memecahkan berbagai masalah kesehatan masyarakat (Ichsan \& Rahmayanti, 2020; Vidergor, 2018). Suatu upaya yang dapat dilakukan adalah dengan cara memberikan penyuluhan tentang pentingnya menerapkan perilaku hidup bersih dan sehat (PHBS) yang lebih intens khususnya kepada masyarakat yang tinggal di wilayah rawan banjir seperti halnya pada masyarakat di Sungai Lulut Banjarmasin. Penyuluhan dan pendidikan tentang menjaga kesehatan diri dan lingkungan kepada masyarakat di wilayah banjir dapat dilakukan melalui berbagai media, tujuannya untuk meningkatkan pemahaman, kepedulian dan peran masyarakat. (Lindarto et al., 2018; Shalihati et al., 2016).

Sosialisasi penaganan bencana banjir sudah dilakukan oleh pemerintah Kota Banjarmasin, tetapi belum menyeluruh mencapai pada aspek kesehatan masyarakat yang spesifik sesuai kondisi masyarakatnya dan belum ada hasil yang signifikan.

Hal ini menjadikan pertimbangan perlu dilakukan kegiatan pengabdian pada masyarakat (PKM) melalui penyuluhan lebih lanjut sebagai upaya mengatasi permasalahan kesehatan masyarakat di wilayah bantaran sungai Lulut, dengan target sasaran adalah keluarga, terutama ibu-ibu rumah tangga.

Tujuan PKM ini adalah untuk memberikan edukasi tentang pentingnya peran rumah tangga dan dalam menerapkan perilaku hidup bersih dan sehat (PHBS) di lingkungan bantaran sungai dan rawan banjir sebagai upaya mitigasi bencana banjir. Target PKM ini yaitu lebih dari $75 \%$ sasaran kegiatan 
memahami penerapan PHBS dalam rumah tangga dan di masyarakat yang berada di lingkungan bantaran Sungai Lulut Banjarmasin, sebagai upaya mitigasi bencana banjir.

\section{METODE}

Pendekatan dan partisipasi mitra sebagai sasaran kegiatan PKM ini, dilakukan dengan terlebih dahulu melakukan koordinasi dengan pengrus RT di Kelurahan Sungai Lulut untuk penentuan dan pemilihan mitra sasaran yaitu ibuibu rumah tangga. Hal ini dilakukan mengingat kondisi masyarakat di wilayah sasaran yang belum banyak memiliki fasilitas handphone dengan aplikasi network (WhatsApp., google dll.). terpilihnya Diharapkan target sasaran adalah ibuibu rumah tangga yang aktif dalam kegiatan masyarakat, sehingga sasaran terbiasa dengan mudah dalam menginformasikan hasil kegiatan PKM ini pada anggota keluarga maupun masyarakat lainnya yang berbatasan dengan wilayah Sungai Lulut ini. Sasaran PKM ini adalah Ibu rumah tangga yang aktif dalam kegiatan pengajian/yasinan, kader kesehatan, pos yandu, serta bersedia mengikuti kegiatan PKM ini sesuai prosedur kesehatan (prokes).

Pendekatan selanjutnya dengan melakukan pertemuan awal yang dilaksankan oleh tim pelaksana PKM dengan ketua RT, kader kesehatan, dan beberapa ibu-ibu rumah tangga di lingkungan kelurahan Sungai Lulut, untuk mensosialisaikan rencana dan tujuan dari kegiatan PKM, serta kesepakatan waktu pelaksanaannya. Pada tim pelaksana juga melaksankan koordinasi persiapan sarana dan prasarana yang akan digunakan dalam pelaksanaan PKM ini. Selanjutnya menentapkan time frame kegiatan, menetapkan design pengabdian, membuat instrument, pembuatan draf materi kegiatan penyuluhan, serta menetapkan jadwal kegitatan PKM.

Metode pelaksanaan Materi penyuluhan pada kegiatan PKM ini disampaikan secara sederhana, informatif dan menarik dengan menggunakan media-media poster, video peraga tentang pengetahuan tentang PHBS di rumah tangga dan masyarakat di bantaran sungai, juga peran serta keluarga dan masyarakat untuk dalam menjaga kesehatan dan kelestarian lingkungan sungai sebagai upaya mitidasi bencana banjir. Materi penyuluhan meliputi pengetahun tentang 10 unsur pokok PHBS dalam rumah tangga/masyarakat, serta pentingnya peran masyarakat dalam menjaga kesehatan dan kebersihan limgkungan sungai sebagai upaya mitigasi banjir.

Keberhasilan terhadap PKM yang dilakukan, diperoleh berdasarkan hasil jawaban kuisioner dari mitra sasaran. Kuisioner berupa soal pretest dan posttest yang berkaitan dengan materi penyuluhan. Penilaian keberhasilan kegiatan ini terlihat dari peningkatan pengetahuan dan pemahaman mitra sasaran tentang bentuk-bentuk PHBS di rumah tangga dan masyarakat bantaran sungai dalam menjaga kesehatannya, serta peranannya dalam mitigasi banjir.

\section{HASIL DAN PEMBAHASAN}

Kegiatan pengabdian kepada masyarakat ini dilaksanakan di Kelurahan Sungai Lulut, yang merupakan wilayah kelurahan paling luas di Banjarmasin dan merupakan wilayah rawan banjir. Dampak banjir menjadikan lingkungan masyarakat setelah bencana banjir yang kurang hygienis dan beberapa anggota masyarakat masih menggunakan air sungai untuk aktvitasnya, seperti tampak pada Gambar 1 dan 2.

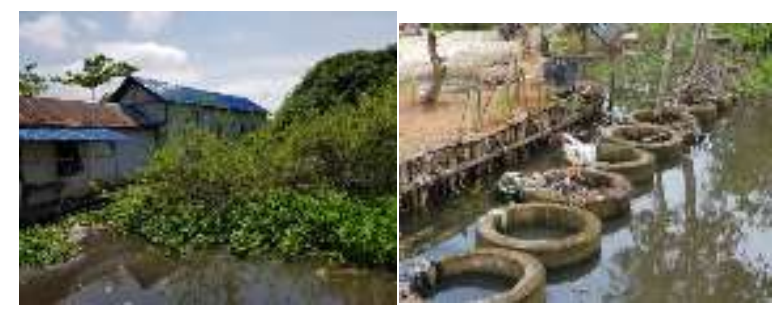

Gambar 1. Lingkungan Warga Masyarakat Sungai Lulut 


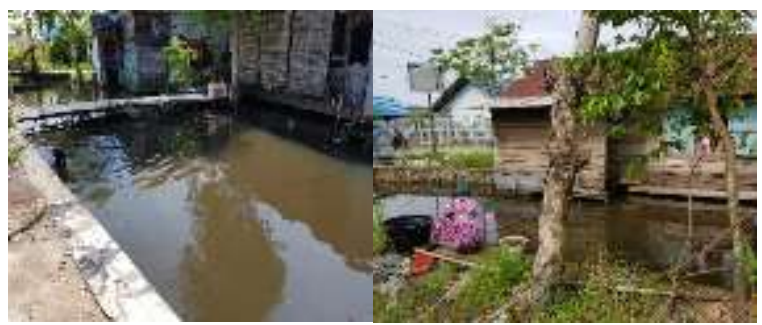

Gambar 2. Aktivitas Masyarakat di bantaran sungai (mandi, mencuci)

Kegiatan ini dilaksanakan secara offline pada 18-19 Juni 2021, bertempat di Masjid Kelurahan Sungai Lulut. Sasaran/ peserta kegiatan PKM adalah ibu-ibu rumah tangga di lingkungan Kelurahan Sungai Lulut Banjarmasin. Semua peserta kegiatan adalah anggota masyarakat yang terdampak bencana banjir bandang yang terjadi pada Januari 2021. Jumlah peserta yang hadir mengukuiti keagitan PKM ini adalah sebanyak 30 orang.

Edukasi yang dilaksanakan pada kegiatan ini adalah melalui metode penyuluhan, ditunjang dengan media peraga berupa slide (ppt), poster, dan video. Materi yang disampaikan diataranya: (1) penerapkan PHBS dalam keluarga dan masyarakat, agar terciptanya masyarakat di bantaran sungai yang sehat, dan (2) penerapan perilaku masyarakat dibantaran sungai untuk menjaga keshatan dan kelestarian lingkungan sungai sebagai upaya mitigasi bencan banjir. Tindakan pencegahan dan mitigasi merupakan kunci penerapan di pelayanan kesehatan dan masyarakat. Perilaku Hidup Bersih dan Sehat (PHBS) merupakan salah satu cara pencegahan dari penularan penyakit infeksi seperti Covid 19. (Kemenkes RI, 2020).

Edukasi PHBS dan kelestarian sungai sebagai upaya mitigasi banjir diisampaikan secara sederhana ditunjang dengan contoh-contoh yang dapa dilaksankan dalam kehidupan sehari-hari dalam keluarga dan masyarakat di bantaran sungai. Sesuai panduan kementrian kesehataan, aspek PHBS, melipuputi: (1) persalinan di tolong oleh tenaga kesehatan, (2) memberi bayi ASI ekslusif,
(3) menimbang balita setiap bulan, (4)

menggunakan air bersih, (5) mencuci tangan dengan sabun dan air bersih, (6) menggunakan jamban sehat, (7) memberantas jentik di rumah sekali seminggu, (8) makan buah dan sayur setiap hari, (9) melakukan aktifitas fisik setiap hari, dan (10) tidak merokok di dalam rumah. Aspek perilaku masayarakat dalam melestraikan keseahtan lingkungan sungai sebagai upaya mitigasi banjir meliputi: (1) penanganan sampah rumah tangga dan masyarakat, (2) penanaman dan perawatan tanaman di halaman rumah, (3) penampungan air hujan dalam rumah tangga, (4) penjadwalan kerja bakti kebersihan sekitar sungai, dan (5) rutinitas pengelolaan sampah di TPS. (Gani et al., 2015, Kemenkes RI, 2020).

Semua peserta kegiatan sangat antusias dengan hadir dan akitf mengikuti kegiatan dari awal sampai akhir kegitaan PKM. Berikut disajikan gambaran suasana kegiatan PKM serta hasil pretest dan posttest dari peserta kegiatan PKM ini.

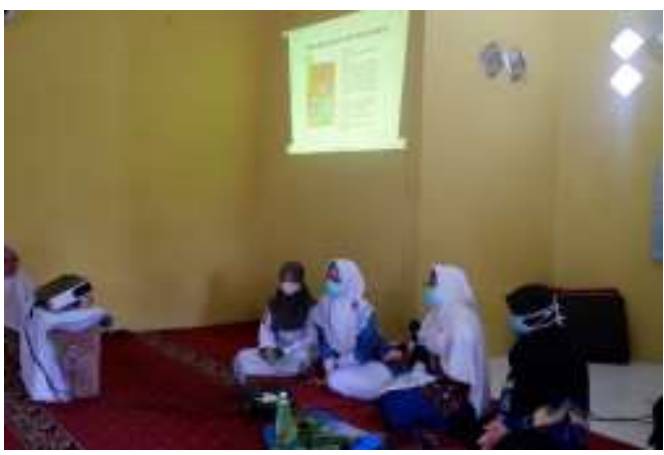

Gambar 1. Penyampaian Materi
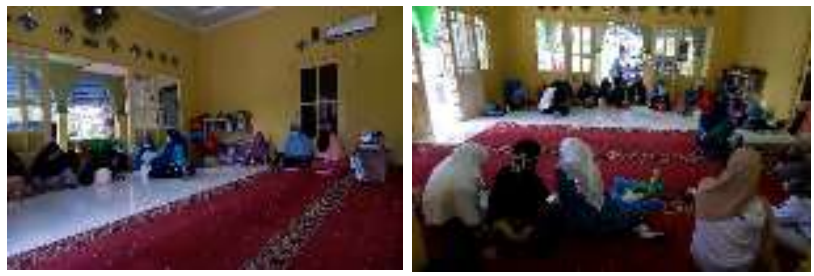

Gambar 2. Suasana kegiatan

Tabel 1. Hasil postest pemahaman peserta kegiatan tentang PHBS dalam menjaga kesehatan keluarga di lingkungan bantaran sungai 


\begin{tabular}{ccccc}
\multirow{2}{*}{ Pengetahuan } & \multicolumn{4}{c}{ Presentase (\%) } \\
\cline { 2 - 5 } & $\mathrm{N}$ & Pretest & $\mathrm{N}$ & Posttest \\
\hline Baik & 4 & 13,33 & 25 & 83,0 \\
\hline Cukup & 18 & 60,00 & 5 & 0,17 \\
\hline Kurang & 8 & 26,67 & 0 & 0,0 \\
\hline Jumlah & 100 & & 100 \\
\hline
\end{tabular}

Tabel 2. Perilaku masyarakat dalam melestarikan kesehatan lingkungan sungai sebagai mitigasi banjir

\begin{tabular}{ccccc}
\hline \multirow{2}{*}{ Pengetahuan } & \multicolumn{4}{c}{ Presentase (\%) } \\
\cline { 2 - 5 } & $\mathrm{N}$ & Pretest & $\mathrm{N}$ & Posttest \\
\hline Baik & 2 & 6,70 & 24 & 80,00 \\
\hline Cukup & 22 & 73,33 & 6 & 20,00 \\
\hline Kurang & 6 & 20,00 & 0 & 0,0 \\
\hline Jumlah & 100 & & 100 \\
\hline
\end{tabular}

Tabel 1 dan 2 memperlihatkan ada peningkatan pengetahuan dan pemahaman peserta yang mengikuti kegiatan edukasi mengenai PHBS dan melestarikan kesehatann lingkungan sungai pada masyarakat di bantaran Sungai Lulut sebagai upaya mitigasi bencana banjir. Persentase pemahaman peserta kegiatan tentang PHBS dalam menjaga kesehatan keluarga di lingkungan bantaran sungai, setelah diberikan edukasi rata-rata adalah baik yaitu sekitar 83\%; sedangkan perilaku yang dapat diterapkan oleh anggota masyarakat dalam melestarikan kesehatan lingkungan sungai sebagai mitigasi banjir, didapatkan presentasi rata-rata yang baik yaitu sekitar $80 \%$. Hasil kegiatan ini melebihi target yang diharapkan yaitu sekitar $75 \%$, mengingat kondisi masyarakat pada saat kegiatan dilakukan, masih dalam proses pemulihan dari wabah bencana banjir dan masa pandemic Covid19.

Berdasarkan hasil analisis situasi dan pretest ada lima dimensi PHBS dan emapat dimensi perilaku masyarakat dalam melestarikan kesehatan sungai sebagai upaya mitigasi banjir, yang perlu ditingkatkan pada masyarakat di bantaran Sungai Lulut. Dimensi PHBS meliputi (1) menggunakan air bersih, (2) mencuci tangan dengan air bersih dan sabun, (3) menggunakan jamban sehat, (4) makan buah dan sayur setiap hari, (5) melakukan aktivitas fisik, dan (6) dan tidak merokok. Sedangkan dimensi pelestarian sungai meliputi : (1) perilaku pengelolaan sampah dari tataran rumah tangga dan lingkungan masyarakat, (2) penanaman dan perawatan tanaman di sekitar sungai, (3) penampungan air hujan dalam rumah tangga, dan (4) penjadwalan kerja bakti kebersihan sekitar sungai.

Rendahnya dimensi PHBS dan perilaku masyarakat di lingkungan bantaran sungai tidak lepas dari rendahnya pengetahuan, kesadaran, dan sikap masyarakat tentang PHBS. Pengetahuan yang rendah berdampak pada perilaku masyarakat yang masih menggunakan air sungai untuk aktivitas sehari hari tanpa memperhatikan kualitas dan higenisitas air yang digunakan. Selain itu sebagaian masyarakat masih ada yang melakukan aktifitas keseharian dengan menggunkan air sungai.

Beberapa faktor yang dapat mempengaruhi pengetahuan, kesadaran, dan sikap masyarakat tentang PHBS dan kepedulian dalam pelestarian kesehatan lingkungan sungai sebagai upaya mitigasi banjir, diantanya adalah umur, tingkat Pendidikan ibu rumah tangga, lingkungan pekerjaan kepala keluarga, penghasilan /ekonomi keluarga, serta jumlah anggota keluarga.

Umur merupakan salah satu faktor internal yang diperkirakan dapat mempengaruhi perilaku seseorang dalam melakukan PHBS dan kepedulian dalam rumah tanggannya. Umur adalah lamanya waktu hidup yaitu terhitung sejak lahir sampai dengan sekarang (Layya et al., 2016). Umur yang semakin tua maka semakin banyak pula pengalaman yang dimiliki, sehingga pengetahuannya makin bertambah. Banyaknya pengetahuan tersebut dapat membuat seseorang akan lebih siap dalam menghadapi sesuatu (Notoatmodjo, 2012). Bertambahnya usia seseorang, biasanya diiringi juga dengan perubahan perilaku. Semakin bertambahnya umur maka biasanya akan membuat seseorang akan semakin sulit untuk menerima sebuah informasi. Mereka menjadi kurang aktif, mudah terkena penyakit, dan cenderung tidak peduli terhadap perilaku hidup bersih dan sehat.

Tingkat pendidikan dapat berpengaruh pada PHBS dalam rumah tangga atau keluarga. Tingkat pendidikan yang kurang menyebabkan rendahnya 
kesadaran seseorang akan pentingnya kebersihan lingkungan. Apabila seseorang mempunyai pendidikan formal yang baik, maka kesadaran dalam menjaga kesehatan keluarga dadn lingkungannya termasuk pemahamannya mengenai penerapan prinsip-prinsip PHBS juga semakin baik. Pendidikan merupakan serangkaian proses dalam membentuk perilaku pada individu (Wati \& Ridlo, 2020). Pada anggota keluarga yang memiliki tingkat pendidikan dan pengetahuan yang baik, serta kebiasaan melaksankan PHBS, maka akan terbina rumah tangga yang rutin menerapkan PHBS, sehingga dapat tercapainya kehidupan keluarga yang sehat, sehingga penting melakukan PHBS dalam kehidupan sehari-hari. (Layya et al., 2016 ; Jamil L, 2019)

Faktor lingkungan pekerjaan merupakan salah satu faktor yang mempengaruhi pengetahuan seseorang. Lingkungan pekerjaan dapat memberikan pengaruh besar bagi seseorang, dimana seseorang dapat mempelajari banyak hal yang baik dan juga hal-hal yang buruk tergantung pada sifat kelompok lingkungan kerjanya. Menurut Layya et al., 2016, ada hubungan antara pekerjaan responden dengan penerapan PHBS dalam tatanan rumah tangga.

Perilaku PHBS pada tatanan rumah tangga dapat pengeruhi oleh tingkat pendapatan (ekonomi) keluarga. Penghasilan keluarga responden dengan tingkat pendapatan tinggi 2,23 kali berpeluang lebih besar untuk menerapkan perilaku PHBS dibandingkan dengan responden yang berpenghasilan rendah. Semakin tinggi pendapatan seseorang, maka upaya yang dilakukan responden tersebut dalam menjaga kesehatannya ataupun untuk menghindari penyakit akan semakin meningkat pula (Khairunnisa dan Nurlaella Hadi, 2014).

Keluarga adalah sebuah sistem sosial kecil yang terbuka terdiri atas suatu rangkaian bagian yang sangat bergantung dan dipengaruhi baik oleh struktur internal maupun lingkungan dan eksternalnya (Friedman, 2010). Rumah tangga merupakan tempat dimana individu sebagai anggota keluarga hidup dan tumbuh serta melakukan aktifitas sehari-hari. Pada keluarga dengan sosioekonomi rendah dan memiliki jumlah anggota keluarga yang banyak, maka kecukupan akan gizi dan aspek kesehatan keluarga menjadi berkurang, karena penghasilan keluarga digunakan oleh banyak orang. Suatu keluarga besar karena besarnya tanggungan, sulit memiliki kapasitas rumah yang sehat, sehingga harus tinggal dalam rumah secara berdesakan yang memudahkan terjadinya penularan penyakit menular (Hapsari, 2010; Jamil L, 2019).

Perilaku hidup bersih dan sehat merupakan segala perilaku kesehatan dengan kesadaran sendiri sehingga anggota keluarga dapat menolong dirinya di bidang kesehatan dan berperan aktif dalam kegiatan kesehatan di masyarakat (Natsir, 2019 ; Jamil L, 2019). PHBS di Rumah Tangga merupakan upaya untuk memberdayakan anggota rumah tangga agar tahu, mau dan mampu melaksanakan perilaku hidup bersih dan sehat serta berperan aktif dalam gerakan kesehatan di masyarakat, termasuk di lingkungan bantaran sungai.

Terdapat banyak manfaat bagi keluarga/rumah tangga maupun masyarakat yang menerapakan PHBS dalam kehidupan sehari-hari. Manfaat penerepan PHBS dalam keluarga yaitu: (1) setiap anggota keluarga menjadi sehat dan tidak mudah sakit, (2) anak tumbuh sehat dan cerdas, (3) anggota keluarga giat bekerja, (4) pengeluaran biaya rumah tangga dapat ditujukan untuk memenuhi gizi keluarga, serta (5) pendidikan dan modal usaha untuk menambah pendapatan keluarga. Manfaat penerapan PHBS ditataran masyarakat diantaranya adalah: (1) masyarakat mampu mengupayakan lingkungan sehat, (2) masyarakat mampu mencegah dan menanggulangi masalah masalah kesehatan, (3) masyarakat dapat memanfaatkan pelayanan kesehatan yang ada, serta (4) masyarakat mampu mengembangkan Upaya Kesehatan Bersumber Masyarakat (UKBM) seperti Posyandu, tabungan ibu bersalin, arisan 
jamban, ambulans desa dan lain-lain. (Natsir, M. F, 2019; Jamil L, 2019)

Menurut teori Benyamin Blum dalam Djafar dkk, 2013, bahwa pengetahuan atau kognitif merupakan domain yang sangat penting untuk terbentuknya tindakan seseoang. Dalam teori tersebut pula dijelaskan bahwa sikap/perilaku merupakan faktor terbesar kedua setelah faktor lingkungan yang mempengaruhi kesehatan individu atau masyarakat.

Kegiatan edukasi dalam peningkatan pengetahuan dan sikap sangat penting dilakukan, sebagai proses awal dalam peningkatan perubahan perilaku. Informasi merupakan salah satu dari kekuatan yang dapat mempengaruhi sebuah persepsi, sistem kepercayaan atau sikap individu. (Mahfudhah D, 2012). Pemberian edukasi PHBS dan upaya penerapan perilaku melestarikan kesehatan lingkungan sungai oleh masyarakat setempat dapat meningkatkan penegetahuan, meningkatkan kepedulian pada lingkungannya sehingga masyarakat mempunyai upaya dalam mitigasi bencana banjir. Pemberian penyuluhan, dapat menambah pengetahuan pada masyarakat serta sikap yang akan lebih baik lagi (Djafar, 2013).

Berdasarkan hasil evaluasi pada kegiatan PKM ini, didapatkan bahwa lebih dari $75 \%$ mitra sasaran paham mengenai pentingnya penerpan PHBS dalam keluarga dan masyarakat dan penerapan menjaga kesehatan dilingkungan bantaran sungai sebagai upaya mitigasi bencana banjir. Edukasi melalui penyuluhan dan sosialisasi cukup efektif dalam meningkatkan pengetahuan dan sikap masyarakat. Hal senada dikemukakan (Fuady, 2017), kampanye dan sosialisasi merupakan kegiatan yang efektif untuk meningkatkan pengetahuan dan literasi masyakat. Kampanye dan sosialisasi merupakan kegiatan yang perlu dilakukan secara berkesinamanbungan untuk meningkatkan pengetahuan dan literasi masyarakat di wilayah bantaran sungai dan rawan banjir.

\section{KESIMPULAN}

Setelah mendapat edukasi, didapatkan peningkatan pengetahuan dan pemahaman masyarakat di bantaran Sungai Lulut dalam hal penerpan PHBS dan penerapan perilaku menjaga kelestarian kesehatan lingkungan banatran sungai sebagai upaya mitigasi banjir. Diharapkan mitra sasaran di lingkungan bantarn sungai dapat menerapkan PHBS yang berkelanjutan dan turut berperan aktif dalam menjaga lingkungan bantaran sungai.

\section{UCAPAN TERIMAKASIH}

Ucapan terimakasih disampaikan kepada Fakutas Kedokteran ULM yang telah membantu pembiayaan kegiatan PKM ini, Ucapan terima kasih juga disampaikan kepada segenap RT serta Ibu-Ibu di wilayah Kelurahan Sungai Lulut Banjarmasin. yang terlibat dan memberikan kontribusi dalam kegiatan PKM ini.

\section{REFERENSI}

Badan Penanggulangan Bencana Daerah (BPBD) Kota Banjarmasin. (2021). "Kondisi Kota Banjarmasin dan Penanggulangan bencama Banjir". Januari 2021

Braun, T., Cottrell, R., \& Dierkes, P. (2018). Fostering changes in attitude, knowledge and behavior: demographic variation in environmental education effects. Environmental Education Research, 24(6),899920.https://doi.org/10.1080/13504622. 2017.1343279

Budiarti LY, Laily khariyati, R.Fakhriyadi. (2017). The Relationship Between The Existence of Bacterial Type From Hand and Feces With Water Paping on Elementary School Students on The Riverbanks. Proceeding International Seminar Development of Tropical Diseases Research Based on Wetland and Indonesian Local Wisdom. 03-05 ${ }^{\text {th }}$ November 2017 Banjarmasin, South Kalimantan. ISSN.24773522: 336-347.

Dinas Kesehatan. (2019). Laporan Tahunan Dinas Kesehatan Provinsi Kalimantan 
Selatan tahun 2019. Banjarmasin : Dinas Kesehatan Kalimantan Selatan

Djafar, MI. (2013). Pengaruh Penyuluhan Tentang Kesiapsiagaan Bencana Banjir Terhadap Pengetahuan Dan Sikap Kepala Keluarga Di Desa Romang Tangaya Kelurahan Tamangapa Kecamatan Manggala Kota Makassar. Fakultas Kesehatan Masyarakat. Universitas Hasanuddin

Fuady, I. (2017). Literasi Informasi Kesehatan: Penyuluhan Informasi Dalam Pencegahan HIV AIDS Bagi Masyarakat di Kawasan Wisata Pangandaran. Jurnal Darmakarya. Vol. 6(1).

Friedman. (2010). Buku ajar keperawatan keluarga: Riset, Teori dan Praktek. EGC.

Gani, H. A., Istiaji, E., Pratiwi, P. E., Kesehatan, B. P., Perilaku, I., \& Kesehatan, F. (2015). Perilaku Hidup Bersih Dan Sehat (PHBS) Pada Tatanan Rumah Tangga Masyarakat Using (Studi Kualitatif di Desa Kemiren, Kecamatan Glagah, Kabupaten Banyuwangi) A Qualitative Study in Kemiren Village, Glagah Sub District, Banyuwangi Regency. Jurnal IKESMA, 11(1), 26-35.

Hapsari, N. R. (2010). Analisis Faktor yang Berhubungan dengan Praktik Ibu Rimah Tangga tentang perilaku Hidup Bersih dan Sehat di Desa Tunggulsari Kecamatan Brangsong Kabupaten Kendal tahun 2010.2.http://lib.unnes.ac.id/3200/1/6305.

Hermon, Dedi, (2012), Mitigasi Bencana Hidrometeorologi, Padang: UNP Press

Jamil, L. (2019) 'Hubungan antara Perilaku Hidup Bersih dan Sehat (PHBS) Tatanan Rumah
Tangga dengan Kejadian Diare pada Balita', ARKESMAS (Arsip Kesehatan Masyarakat), 4(1), pp. 125-133.doi:

10.22236/arkesmas.v4i1.3144.

Kemenkes, Direktorat Jenderal Pencegahan dan Pengendalian Penyakit. (2020). Pedoman Pencegahan dan Pengendalian Corona Virus Disease (Covid-19) Rev-05. Kementerian Kesehatan RI : Jakarta.

Kelurahan Sungai Lulut. 2019. Laporan dan Profil Tahunan Kelurahan Sungai Lulut Kecamatan Banjarmasin Timur, Kota Banjarmasin

Khairunnisa dan Nurlaella Hadi, E. (2014). Gambaran perilaku hidup bersih dan sehat tatanan rumah tangga di Kota Depok tahun 2014 dan faktor-faktor yang berhubungan. http://lib.ui.ac.id/naskahringkas/201612//S58299-Khairunnisa

Kew, S. N., Petsangsri, S., Ratanaolarn, T., \& Tasir, Z. (2018). Examining the motivation level of students in e- learning in higher education institution in Thailand: A case study. Education and Information

Layya, Imran, \& Nasarudin. (2016). Perilaku Hidup Bersih Dan Sehat (PHBS) Dalam Tatanan Rumah Tangga Berbasis Kerusakan Akibat Tsunami Di Wilayah Kota Banda Aceh. Jurnal Ilmu Kebencanaan, 3(1), 19-26.

Mahfudhah, D. (2012). Indrapuri Kabupaten Aceh Besar the Relationshipbetweent Knowledge , Behaviour, and Housewives ' Ocupation Toward Clean and Healthy Life Syle in Household Management Inreukih Dayah Village, Indrapuri, Aceh Besar.

Natsir, M. F. (2019). Perilaku Hidup Bersih Dan Sehat (PHBS) Pada Tatanan Rumah Tangga Masyarakat Desa Parang Baddo. Jurnal 
Nasional Ilmu Kesehatan ( JNIK ), 1(3), 5459.

Notoatmodjo, S. (2012). Promosi Kesehatan dan Perilaku Kesehatan. Rineka Cipta.

Notoatmojo S. (2007). Ilmu Kesehatan Masyarakat. Rineka Cipta.

RISKESDAS. 2019. Laporan Hasil Riset Kesehatan Dasar Provinsi Kalimantan Selatan. Depkes. Jakarta

Vidergor, H. E. (2018). Effectiveness of the multidimensional curriculum model in developing higher-order thinking skills in elementary and secondary students. The Curriculum Journal, $\quad$ 29(1), 95-115. https://doi.org/10.1080/09585176.20 $\underline{17.1318771}$

Wati, P. D. C. A., \& Ridlo, I. A. (2020). Hygienic and Healthy Lifestyle in the Urban Village of Rangkah Surabaya. Jurnal Promkes, 8(1), 47.https://doi.org/10.20473/jpk.v8.i1.2020.47 $-58$

Watson, L., Hegtvedt, K., Johnson, C., Parris,C.,\&Subramanyam,S.(2017).When legitimacy shapes environmentally responsible behaviors: Considering exposure to university sustainability initiatives. Education $\quad$ Sciences, $7(1), 13$. https://doi.org/10.3390/educsci7010 013 